\title{
Future impacts of land use and climate change on extreme runoff values in selected catchments of Slovakia
}

\author{
Silvia Kohnová, Peter Rončák, Kamila Hlavčová, Ján Szolgay \\ Slovak University of Technology, Department of Land and Water Resources Management, Radlinského 11, \\ 81005 Bratislava, Slovakia, e-mail: silvia.kohnova@stuba.sk
}

\author{
Agnieszka Rutkowska \\ University of Agriculture in Krakow, Department of Applied Mathematics, Balicka 253c, 30-198 Kraków, Poland
}

\begin{abstract}
The aim of this study is to look at the impacts of land use and climate change on extreme runoff regimes in selected catchments of Slovakia, with an emphasis on selected characteristics of hydrological regimes, catchment runoff, and, especially extreme runoff. Changing climate conditions, characterized especially by changes in precipitation, air temperatures, and potential evapotranspiration in future decades, have been predicted by recent outputs of the KNMI and MPI regional climate change models and the A1B emission scenario. The land use changes were characterized by various future land use scenarios. Assuming these scenarios are accurate, the hydrological regime characteristics were simulated by the WetSpa distributed rainfall-runoff model, which was parameterized for the selected river basins with a daily time step until 2100. Changes in the total runoff and its components (the maximum and design discharges), as well as changes in soil moisture and actual evapotranspiration, compared to the current state, confirm the assumption of an increase in the extremes of the hydrological regimes during periods of flood events. The results of the study showed a need for a reevaluation of design discharge values for future designs of water management structures.
\end{abstract}

Keywords: land use and climate change scenarios, the WetSpa model, design discharge

Submitted 29 March 2018, revised 24 July 2018, accepted 24 August 2018

\section{Introduction}

Environmental changes (including land use changes and climate change) and their impacts on water resources have been topical issues in recent years. According to the Seventh National Communication of the Slovak Republic on Climate Change (2017), the direct or indirect impacts of land use changes and climate change on hydrological regimes have contributed to problems such as droughts and water scarcity, increasingly frequent flash floods, and damage caused by massive deforestation also in the Slovak Republic.

Rainfall-runoff models are often used as tools for assessing the impacts of climate change and land use changes on hydrological cycles. While the modeling of climate change generally relies on conceptual rainfall-runoff models, models with spatially-distributed parameters are needed to simulate the effects of land use changes on runoff in river basins.

The climate and hydrological cycles are strongly coupled with land surface and ecosystem processes, both in the sense that modifications of the water cycle significantly affect land surface properties and the functioning of ecosystems, and because changes in vegetation and land surfaces can significantly affect the whole hydrological cycle and climate (McFarlane et al. 1993).

Climate change caused by rising concentrations of greenhouse gases in the atmosphere may affect the hydrological cycle and the availability of water to humans and therefore can also affect agriculture, forestry, and other industries (e.g., Misra 2014).

Changes in the hydrological cycle may cause more floods in some areas; on the other hand, droughts can predominate in other areas, with an associated increase in pressure on water supplies and irrigation systems (Blauhut et al. 2016; Freire-González et al. 2017). Therefore, it is important to be able to estimate the possible impacts of climate change on water resources and develop strategies for sustainability. One of the challenges in predicting the hydrological responses affected by climate change is the issue of hydrological non-stationarity (e.g., Milly et al. 2008). There are many factors that can affect hydrological stationarity. These include, for example, the response of vegetation to increased $\mathrm{CO}_{2}$ and changes in land use and precipitation characteristics. It is therefore important to better understand the impact of non-stationarity on hydro- 
logical assessments of climate change. The possibilities of estimating or predicting future developments in river basin processes are considerably limited even though there are several different complex and accurate hydrological models, and databases of climatic, geological, and hydrological data, etc. (Mishra, Singh 2010).

Distributed hydrological models (models with spatially-distributed parameters) take into account the spatial variability of atmospheric processes and the physical-geographic characteristics of river basins that control rainfall-runoff processes (Kulhavý, Koláŕ 2000). Physically-based, spatially-distributed hydrological models are capable of using geospatial information directly. The intensive development of computer programs supports exploitation of rich information describing the physical-geographic features of landscapes. A basis for accurate hydrological predictions is also important for accessing relevant data for rainfall and surface characteristics of basins that transform precipitation into runoff.

In Central Europe, many different hydrologicallydistributed models have been used to simulate runoff processes under changed land use and climate conditions. Good examples of such models include: WetSpa (e.g., Wang et al. 1996; Safari et al. 2009; in Slovakia e.g., Valent et al. 2015, 2016; Rončák et al. 2016, 2017a), SWAT (Arnold et al. 1998), and MIKE SHE (e.g., Refsgaard, Storm 1990; Tegelhoffová 2010). This article builds on previously published papers dealing with a similar theme and which use several older outputs of global and regional models, climate change scenarios, and various conceptual and distributed hydrological models (Hlavčová et al. 2008, 2015; Štefunková et al. 2013, Rončák et al. 2017b).
Most of the results of these studies based on outputs of Global climate models (GCM) are not sufficient, because of their coarse spatial scale, especially in the mountainous regions of Slovakia. In these cited papers we were concentrating on estimation of changes in water balance and mean runoff in daily and monthly time steps.

In this paper we will therefore evaluate the possible impacts of land use and climate change on extreme runoff values in selected catchments, where the simulation of future changes in runoff processes are based on the outputs of the regional climate models (RCMs) from Royal Netherlands Meteorological Institute (KNMI) and MaxPlanc Institute in Germany (MPI).

\section{Study area}

In this study two large catchments located in the territory of Slovakia were chosen for modelling. The Laborec River flows from north to south through the Prešov and Košice regions. The main tributaries of the river include the Cirocha and Uh rivers. The Laborec flows into the Latorica River, which, together with the Ondava River, creates the Bodrog River. The river originates in the Low Beskydy Mountains, which are not far from the Polish border. Its length is $129 \mathrm{~km}$, and the river basin is $4520 \mathrm{~km}^{2}$. The Laborec River basin, with the Humenne final profile, an area of $1283.39 \mathrm{~km}^{2}$, and an altitude ranging from 140 to $1160 \mathrm{~m}$ a.s.l., was selected as one of the study areas (Fig. 1) for the rainfall-runoff modelling in this paper.

The Váh River basin with the Váh-Liptovský Mikulás profile was chosen as the second example for this research. The Váh is the longest river in Slovakia. The Váh, includ-

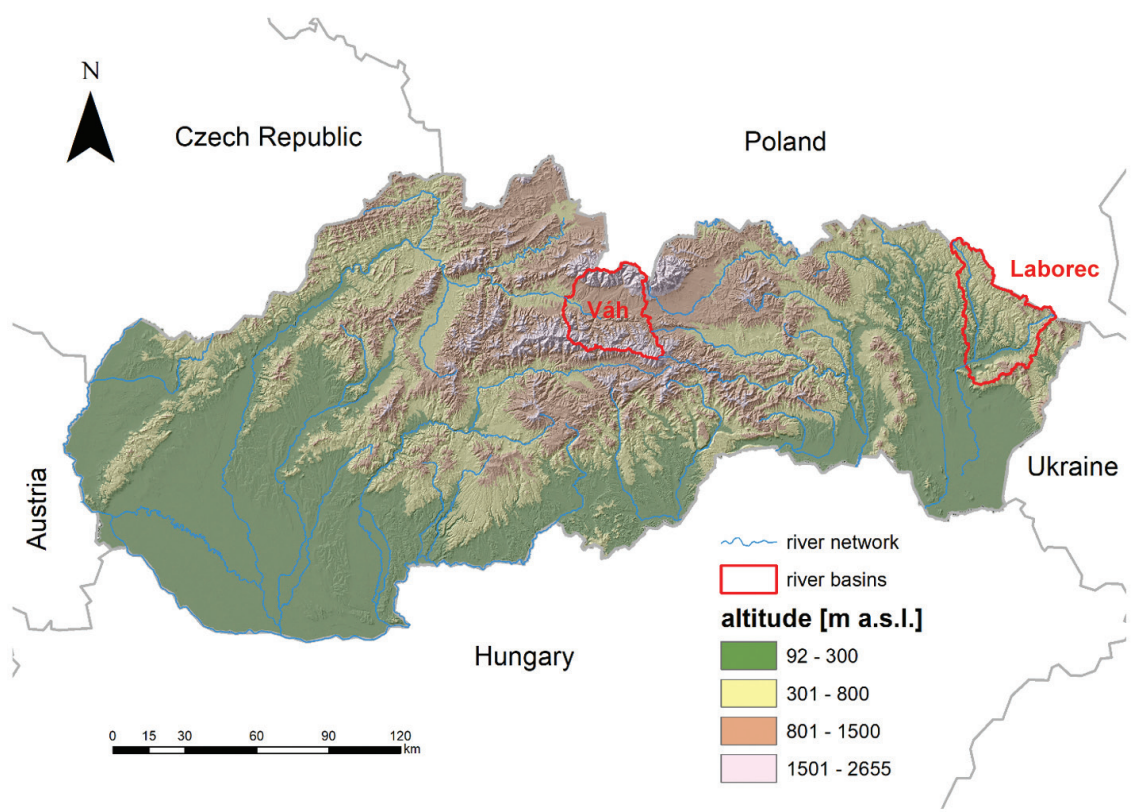

Fig. 1. The location of the selected Váh and Laborec catchments Slovakia 
ing its Čierny Váh branch, is a left tributary of the Danube River with a length of $406 \mathrm{~km}$. Its two sources, the Biely Váh (White Váh) and the Čierny Váh (Black Váh), are located in the Vysoké Tatry (High Tatras) and Nízke Tatry (Low Tatras) mountains, respectively, and it flows over northern and western Slovakia and finally feeds into the Danube River at Komárno. The area of its drainage basin is $10641 \mathrm{~km}^{2}$. The Váh has a large number of tributaries. The east-west valley formed by its upper course provides a natural transportation route across Slovakia, represented by major road and rail arteries; the river's north-south valley between Žilina and Bratislava similarly serves as a corridor. The river flows rapidly - particularly when swollen by seasonal meltwater, since the Tatras have few storage lakes - through a picturesque valley. There are numerous small hydroelectric-power stations along the Váh.

\section{Methodology}

In this work the Water and Energy Transfer between Soil, Plants and Atmosphere (WetSpa) model was used for estimating the impacts of land use changes (in the composition of forests) and global climate change on the runoff regimes in the selected river basins. Our study is based on land use change scenarios of forest associations in combination with global climate change scenarios. A land use change scenario for the 2075 horizon was used to simulate runoff under changed conditions of land use. Outputs from the KNMI and MPI climate scenarios were used to simulate runoff. Both types of change scenarios were prepared, and the runoff under the new conditions was simulated.

\subsection{The rainfall-runoff model}

For simulations of runoff and other components of a hydrological balance under changed conditions, the WetSpa distributed rainfall-runoff model was used. This model uses geospatially referenced data as the input for deriving the model's parameters, which include most data types supported by ArcGIS, such as coverage, shape files, grids, and ASCII files. An image can be used for a reference within a view, but is not used directly by the model. The three base maps used in the model are digital maps of the topography, land use and soil types, while other digital data are optional, depending upon the data available, the purpose, and the accuracy requirements of the project (Wang et al. 1996). We used a modified version of the WetSpa model, which was developed at the Department of Land and Water Resources Management (Rončák 2016).
The following hydro-meteorological data were used in the model: daily precipitation totals from spot measurements at 13 stations in the Váh River basin and 28 stations in the Laborec River basin, along with the average daily air temperature at 11 climatological stations in the Váh catchment and 7 climatological stations in the Laborec catchment. The flow data consisted of the average daily flows at the Váh-Liptovský Mikuláš and LaborecHumenné profiles.

The model was calibrated for the 15-year period from 1981 to 1995. The Nash-Sutcliffe efficiency coefficient (hereinafter "N-S"), a measure of how closely the model reproduces the data, was chosen as the dominant criterion in this work. The N-S value achieved during the model's calibration was 0.642 for the Váh and 0.581 for the Laborec catchment. To eliminate the uncertainty in parameter estimation, cross-calibration and validation of the hydrological model was performed. The validation was carried out for the time period 1996-2010 with an N-S coefficient of 0.627 for the Váh and 0.575 for the Laborec catchment.

\subsection{Preparing land use and climate change scenarios}

Land use scenarios (LU) were created for the entire territory of the Slovak Republic (Škvarenina et al. 1996) by the Technical University of Zvolen and published in the Landscape Atlas of the Slovak Republic. Subsequently, the ArcGIS program was used to process and categorize the data for the needs of the WetSpa rainfallrunoff model. We used a land use change scenario with a forest composition with a horizon of 2075.

Table 1 shows the changes in the land use classes between the current situation and the land use change scenario. Some differences in the forest composition, in general a decrease in forest cover, can be seen.

Table 1. Comparison of the current land use and land use change scenarios in the selected river basins

\begin{tabular}{|l|c|c|c|c|}
\hline \multirow{2}{*}{ Land use classes } & \multicolumn{2}{|c|}{ Váh catchment } & \multicolumn{2}{c|}{ Laborec catchment } \\
\cline { 2 - 5 } & current & scenario & current & scenario \\
\cline { 2 - 5 } & {$[\%]$} & {$[\%]$} & {$[\%]$} & {$[\%]$} \\
\hline Crop and mixed farming & 9 & 8 & 13 & 10 \\
\hline Short grass & 20 & 37 & 14 & 27 \\
\hline Coniferous trees & 56 & 0 & 2 & 0 \\
\hline Mixed trees & 1 & 35 & 4 & 0 \\
\hline Deciduous trees & 8 & 14 & 63 & 60 \\
\hline Deciduous shrub & 1 & 1 & 1 & 1 \\
\hline Impervious area & 2 & 2 & 3 & 3 \\
\hline Bare soil & 3 & 3 & - & - \\
\hline
\end{tabular}


The deciduous forest should increase; on the contrary, the coniferous forest will mainly decrease and move to higher altitudes because of global warming.

These changes in the forest composition result in higher evapotranspiration and to a lesser degree affect interception of precipitation and runoff.

The latest climate change scenarios for the territory of Slovakia were processed on the basis of outputs from climatic atmospheric models at the Department of Astronomy, Earth Physics and Meteorology at the Faculty of Mathematics, Physics and Informatics of Comenius University (Lapin et al. 2012).

In this study, the KNMI and MPI regional models (Lapin et al. 2006) were used to represent a more detailed integration of the dynamic equations of atmospheric and oceanic circulation in a network of grid points at a distance of $25 \mathrm{~km} \times 25 \mathrm{~km}$, while the boundary conditions of the solution to the equation are taken from the outputs of the global ECHAM5 model and the SRES A1B (moderate) which represents a realistic emission scenario. Here we did not assess the impact of more extreme scenarios.

The KNMI and MPI RCMs have $19 \times 10$ grid points (190) in Slovakia and its surroundings with a detailed topography and an appropriate expression of all the topographic elements larger than $25 \mathrm{~km}$.

Tables 2 and 3 illustrate the long-term mean monthly values of the air temperatures and precipitation for the 1981-2010 reference period in the Váh and Laborec River basins and changes in their values for the three future time horizons according to the KNMI and MPI regional climate change scenarios.

According to the individual climatic models, as seen in Tables 2 and 3, a decrease in mean monthly precipitation in the summer period can be expected. On the other hand, the winter period should be more humid in comparison with the current conditions. The mean monthly air temperature will rise, without exception, in the individual river basins at about the same rate. The mean monthly air temperatures will increase with the increasing time horizons.

\subsection{Estimation of the design runoff}

To estimate the changes in the extreme runoff simulated, we conducted a statistical analysis and applied tests to the estimated design runoff for the various return periods, according to the methodology proposed by DVWK Regeln 101 (1999).

The following three methods for estimating distribution function parameters were used:

- the method of moments (MOM);
- maximum likelihood method (ML);

- method of probability weighted moments (PWM).

For estimating the probabilities, the following seven theoretical distribution functions were applied: Extreme Value Distribution as: Generalized Extreme Value, Three and two-parameter Lognormal, Pearson type III, LogPearson type III, Three-parameter Weibull, and Rossi distribution. All distributions were tested using the alternative methods of parameter estimation (MOM, ML, PWM).

The plotting position was estimated according to Cunnane (1988) as:

$$
P=\frac{m-0.4}{n+0.2}
$$

where $n$ - number of observation in years and $m$ is the number of the sequence of the descending sorted data.

To test and select the most appropriate distribution functions, we applied the following statistical tests involved in a combined selection criterion $W$ :

$$
W=K S+C M+\left(1-r^{2}\right)
$$

where the results of the statistical tests were minimized: $K S$ - value of the Kolmogorov test statistic, and $C M-$ Cramer-von Mises test statistic at the significance level of 0.05 .

In the $C M$ test the differences between the theoretical and empirical distribution functions are calculated with the following formula:

$$
\sum_{i=1}^{n}\left[F\left(x_{i}\right)-P_{i}\right]^{2}+\frac{1}{12 n}
$$

where $x_{i}$ - discharge or runoff values $i=1 \ldots, n$ and $F$ - selected theoretical distribution.

$$
P_{i}=\frac{i-0.5}{n}
$$

where $P_{i}$ - plotting position, $r$ - correction coefficient between theoretical and empirical quantiles.

\section{Results}

Using the parameters of the calibrated WetSpa model and the outputs from the KNMI and MPI climate scenarios, flows in the final profiles for the future time periods until the year 2100 were simulated. The 30 -year period from 1981 to 2010 was chosen as the reference period. The LU-KNMI and LU-MPI represent the combination of climate change and land use scenario. 
Table 2. Long-term mean monthly values of air temperatures and precipitation of the reference period 1981-2010 and their difference values for the future time horizons in the Váh River basin

\begin{tabular}{|c|c|c|c|c|c|c|c|c|c|c|c|c|c|}
\hline \multirow{2}{*}{\multicolumn{2}{|c|}{ Temperature }} & \multicolumn{12}{|c|}{ Month } \\
\hline & & I & II & III & IV & V & VI & VII & VIII & IX & $\mathrm{X}$ & XI & XII \\
\hline & & \multicolumn{12}{|c|}{$\left[{ }^{\circ} \mathrm{C}\right]$} \\
\hline \multicolumn{2}{|c|}{$1981-2010$} & -5.1 & -4.4 & -1 & 4.2 & 9.5 & 12.4 & 14.4 & 13.7 & 9.5 & 5.1 & 0.1 & -4 \\
\hline \multirow{3}{*}{ KNMI } & 2025 & 0.3 & 0.9 & 0.9 & 0.3 & 0.9 & 1 & 0.9 & 1 & 1 & 1.6 & 0.5 & 0.1 \\
\hline & 2055 & 1.5 & 2.8 & 1.3 & 1 & 1.7 & 2 & 1.9 & 2 & 1.5 & 2 & 1.5 & 1.8 \\
\hline & 2085 & 2.9 & 2.9 & 2.2 & 1.7 & 2.8 & 3.5 & 3.8 & 3.4 & 2.4 & 3.1 & 3.2 & 3.4 \\
\hline \multirow{3}{*}{ MPI } & 2025 & 0.4 & 1 & 0.3 & 0.1 & 0.7 & 0.7 & 0.6 & 1 & 1 & 1.5 & 0.8 & 0.2 \\
\hline & 2055 & 2.1 & 3.1 & 1.3 & 0.9 & 1.4 & 1.3 & 1.6 & 2.2 & 1.7 & 1.8 & 1.8 & 1.6 \\
\hline & 2085 & 3.4 & 3.5 & 2 & 1.5 & 2.2 & 2.9 & 2.8 & 3.5 & 3.1 & 3.2 & 3.3 & 3.6 \\
\hline \multirow{2}{*}{\multicolumn{2}{|c|}{ Precipitation }} & I & II & III & IV & $\mathrm{V}$ & VI & VII & VIII & IX & $\mathrm{X}$ & $\mathrm{XI}$ & XII \\
\hline & & \multicolumn{12}{|c|}{$[\mathrm{mm}]$} \\
\hline \multicolumn{2}{|c|}{$1981-2010$} & 47.8 & 42.7 & 53.8 & 54.3 & 93.5 & 96 & 106.2 & 85.2 & 69.8 & 59.3 & 61.1 & 55.6 \\
\hline \multirow{3}{*}{ KNMI } & 2025 & -4 & 1 & -3 & -6 & -12 & 3 & -17 & 5 & 33 & -3 & 3 & 19 \\
\hline & 2055 & 4 & 5 & 8 & 14 & -5 & -13 & -16 & 3 & 17 & 6 & 1 & 22 \\
\hline & 2085 & 14 & 17 & 21 & 8 & -22 & -30 & -31 & -4 & 37 & 11 & 3 & 26 \\
\hline \multirow{3}{*}{ MPI } & 2025 & 1 & 5 & -2 & -3 & -12 & 18 & 6 & -3 & 20 & -5 & 5 & 13 \\
\hline & 2055 & 9 & 3 & 12 & 20 & -14 & 10 & -4 & -6 & 13 & 8 & -1 & 20 \\
\hline & 2085 & 17 & 14 & 19 & 15 & -16 & -3 & -15 & -4 & 23 & 14 & 10 & 17 \\
\hline
\end{tabular}

Table 3. Long-term mean monthly values of air temperatures and precipitation of the reference period 1981-2010 and their difference values for the future time horizons in the Laborec River basin

\begin{tabular}{|c|c|c|c|c|c|c|c|c|c|c|c|c|c|}
\hline \multirow{2}{*}{\multicolumn{2}{|c|}{ Temperature }} & \multicolumn{12}{|c|}{ Month } \\
\hline & & I & II & III & IV & V & VI & VII & VIII & IX & $\mathrm{X}$ & XI & XII \\
\hline & & \multicolumn{12}{|c|}{$\left[{ }^{\circ} \mathrm{C}\right]$} \\
\hline \multicolumn{2}{|c|}{$1981-2010$} & -4.9 & -4.2 & -0.8 & 4.3 & 9.6 & 12.4 & 14.4 & 13.9 & 9.6 & 5.3 & 0.3 & -3.6 \\
\hline \multirow{3}{*}{ KNMI } & 2025 & 1.3 & 2.6 & 3.3 & 3.4 & 4 & 4.1 & 3.6 & 3.6 & 3.3 & 3.5 & 2.6 & 1.8 \\
\hline & 2055 & 2.7 & 4.6 & 3.8 & 4.2 & 4.6 & 5.2 & 4.8 & 4.5 & 3.8 & 3.9 & 3.5 & 3.3 \\
\hline & 2085 & 4.1 & 4.8 & 4.8 & 4.8 & 5.7 & 6.5 & 6.5 & 5.8 & 4.7 & 5 & 5.3 & 4.9 \\
\hline \multirow{3}{*}{ MPI } & 2025 & 1.6 & 2.7 & 2.7 & 3.2 & 3.8 & 4 & 3.5 & 3.5 & 3.2 & 3.4 & 2.9 & 1.9 \\
\hline & 2055 & 1.6 & 2.7 & 2.9 & 3.5 & 3.9 & 4.1 & 3.6 & 3.4 & 3.1 & 3.2 & 2.8 & 1.7 \\
\hline & 2085 & 3.4 & 4.9 & 4 & 4.1 & 4.5 & 4.4 & 4.3 & 4.5 & 3.9 & 3.8 & 3.8 & 3.1 \\
\hline \multirow{2}{*}{\multicolumn{2}{|c|}{ Precipitation }} & I & II & III & IV & V & VI & VII & VIII & IX & $\mathrm{X}$ & XI & XII \\
\hline & & \multicolumn{12}{|c|}{$[\mathrm{mm}]$} \\
\hline \multicolumn{2}{|c|}{ 1981-2010 } & 50.9 & 45.6 & 46.9 & 58.2 & 83.8 & 98.5 & 105.3 & 76.4 & 80.2 & 56.5 & 58.2 & 64.1 \\
\hline \multirow{3}{*}{ KNMI } & 2025 & -9 & 5 & -5 & -10 & -15 & 9 & -7 & -0.4 & 23 & 5 & 8 & 9 \\
\hline & 2055 & -0.2 & 5 & 8 & 12 & -8 & 9 & -15 & -10 & 17 & 13 & 0 & 17 \\
\hline & 2085 & 10 & 14 & 14 & 5 & -11 & -25 & -19 & 0.3 & 42 & 10 & 10 & 17 \\
\hline \multirow{3}{*}{ MPI } & 2025 & -3 & 10 & -6 & -5 & -10 & -3 & -11 & 3 & 19 & 5 & 5 & 8 \\
\hline & 2055 & 6 & -0.3 & 11 & 16 & -12 & 5 & -7 & -1 & 10 & 14 & -7 & 22 \\
\hline & 2085 & 11 & 9 & 19 & 19 & -11 & -18 & -29 & -12 & 17 & 13 & 8 & 12 \\
\hline
\end{tabular}

The future changes in runoff due to climate and land use changes were evaluated by comparing the simulated average daily flows and their statistical characteristics for the current state and the modelled scenarios (Figs. 2 and 3).

By comparing the long-term mean monthly runoff from the 1981-2010 reference period with the outputs of the scenarios, we can see that in both catchments, the runoff regime will change. The moderate increase in long-term average annual flow rates is directly related to the increasing time horizon, which is due to the increasing precipitation aggregate in the future.

The Váh River basin (Fig. 2) will be characterized by an increase in average monthly flows, especially in the winter months. This will apply to both scenarios and 
horizons, but according to the KNMI scenario, a $100 \%$ increase over the last horizon can be expected in January and February. The sensitivity to climate change in the summer months will respond in an opposite manner. According to the KNMI scenario, the average monthly flow rates will fall gradually by $-2,-60 \%$ from May to August. In the autumn, an increase in runoff in both scenarios can be expected, compared to the flow rates in the reference period under the current climate conditions.

The common feature for both river basins, with few exceptions, is a decrease in runoff in the months from March to August. Maximum increases in long-term mean

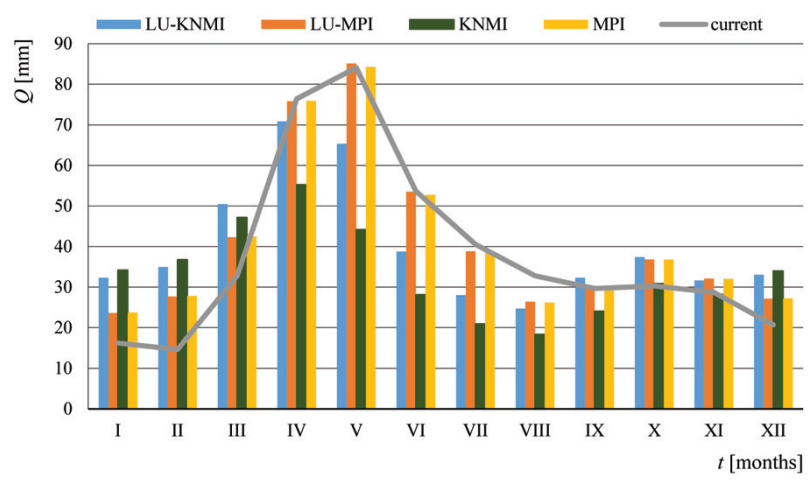

Fig. 2. Comparison of the long-term mean monthly runoff in the Váh River basin between climate scenarios MPI and KNMI and combination of land use and climate scenarious LU-KNMI and LU-MPI, and the current state

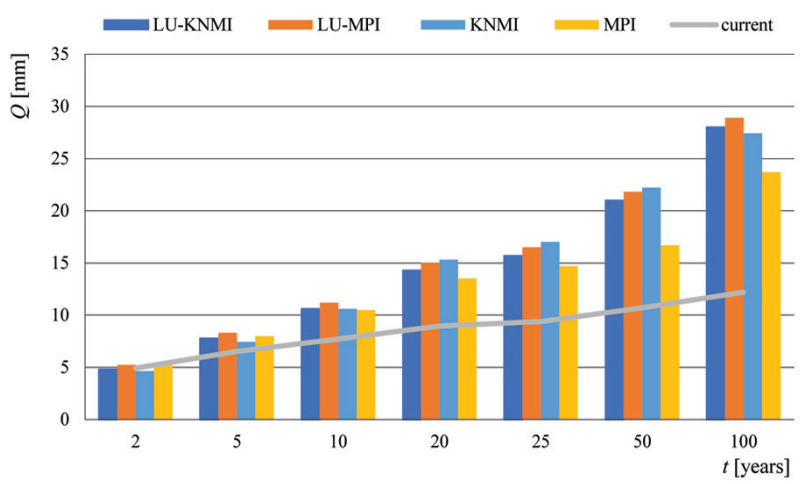

Fig. 4. Comparison of the annual maximum design daily runoff in the summer period for several scenarios in the Váh River basin

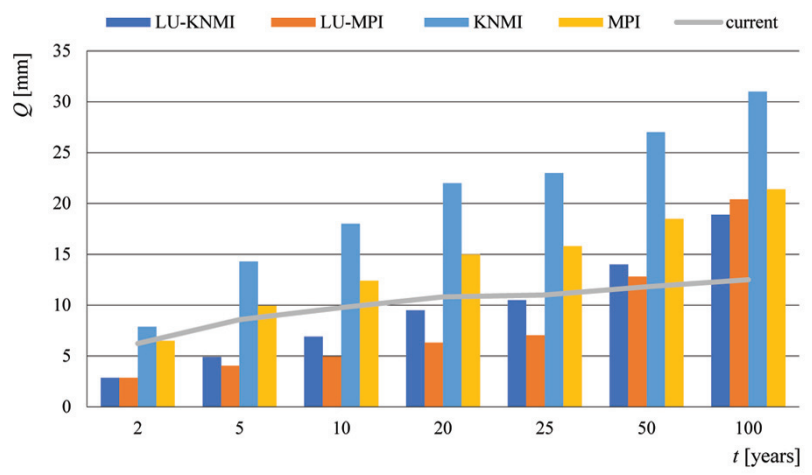

Fig. 6. Comparison of the annual maximum design daily runoff in the summer period for several scenarios in the Laborec River basin monthly discharges in the Laborec basin (Fig. 3) may mainly occur in January (according to the KNMI scenario by $14-63 \%$, according to the MPI scenario, by $45 \%$ ). For the growing season the drainage in both catchments will be typical. According to the MPI scenario, a decrease of up to $45 \%$ can be expected in the Laborec catchment area.

The land use change scenarios (LU-MPI and LU-KNMI) will not have a significant effect on the long-term mean monthly discharges in both river basins.

Next, we have focused on a comparison of the estimated values of the design annual mean daily maximum /runoff modelled in two seasons, i.e., the summer season

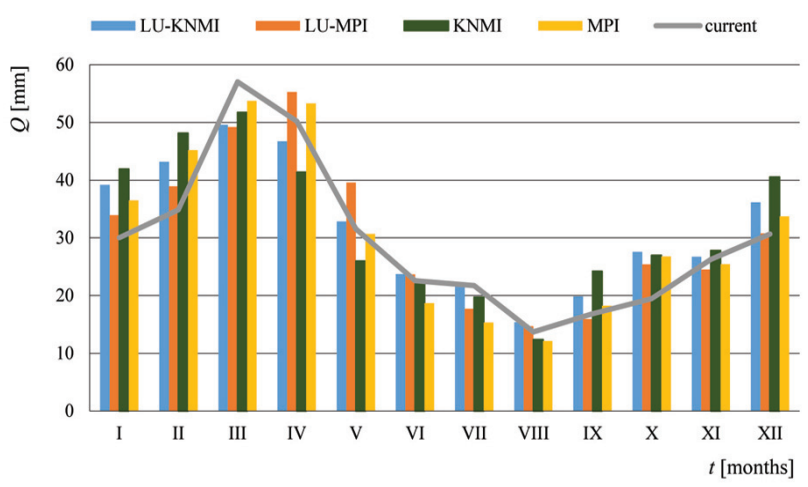

Fig. 3. Comparison of the long-term mean monthly runoff in the Laborec River basin between climate scenarios MPI and KNMI and combination of land use and climate scenarious LU-KNMI and LU-MPI, and the current state

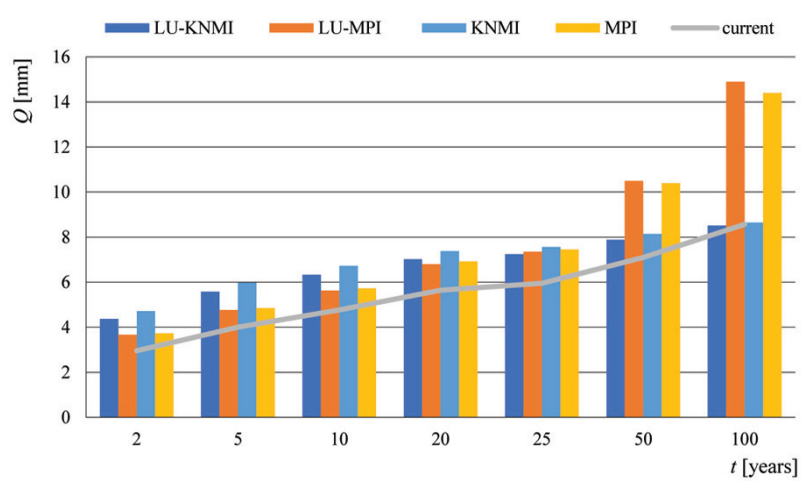

Fig. 5. Comparison of the annual maximum design daily runoff in the winter period for several scenarios in the Váh River basin

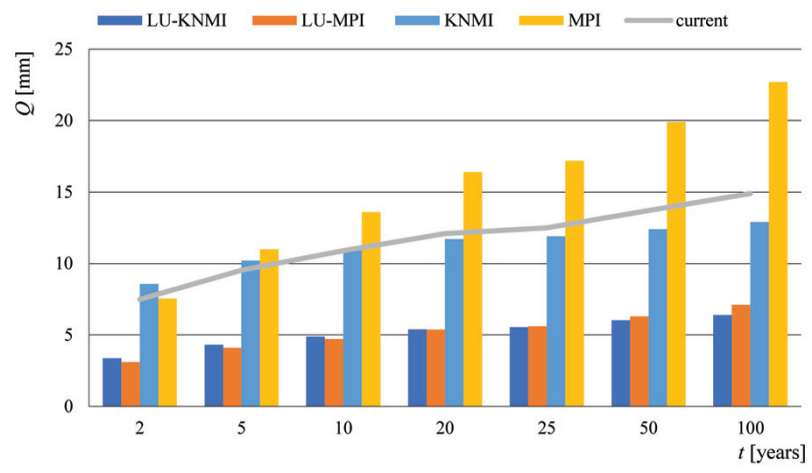

Fig. 7. Comparison of the annual maximum design daily runoff in the winter period for several scenarios in the Laborec River basin 
(April-September) and the winter season (OctoberMarch), for the selected scenarios.

For the estimation of design runoff we used the samples of annual, winter, and summer annual maximum runoff for the Váh and Laborec Rivers (for real observations, KNMI and MPI scenarios for climate change, and scenarios with land use changes, altogether 15 samples of data series). To lower the uncertainty in selection of the distribution function and the parameter estimation method, we tested 7 types of statistical models (distribution functions) for each data sample for each combination of the three methods of parameter estimation. The tested distribution functions (together 315 cases) were required to pass the correlation test, Kolmogorov-Smirnov (KS), and Cramer-von Mises (CM) tests at the significance level $p=0.05$. Finally, to reduce the uncertainty in selection of the best distribution function for each sample we applied the selection criterion according to the Eq. 2, DVWK (1999). The results are presented in Figures 4-7.

If we compare the trends in the increases in the design runoff for the individual scenarios, we can see that they react differently in the two river basins analyzed.

An increase in the design runoff of up to $100 \%$ for the high return periods can be observed in the Váh River basin for both seasons. The KNMI and LU-KNMI scenarios did not differ greatly, but the effect of the land use changes is more dominant in the summer season than in the winter period. The MPI scenarios present an increase in extreme runoff of more than $30 \%$ in the winter months.

In the Laborec River basin we can observe a decrease in the design runoff in comparison to the current state, especially in scenarios that combine the land use with climate change in the summer and winter. In the winter months the changes in land use in the future can predominantly affect snowmelt and winter floods. The reduction of the number of floods is up to $100 \%$ for all the return periods analyzed.

As a result of the changes in land use, there will be a decrease in the annual maximum design daily runoff in the winter period for the land use change scenarios (LUMPI and LU-KNMI). There may be several reasons for this finding. Forestry in the catchment does not change significantly, but changes occur in the forest's composition. Also, the percentage of grassland increases. It should also be noted that during the creation of the input maps of the land use scenarios, those areas that could not be categorized were replaced by the category of short grass. This could affect the decrease in the annual maximum design daily runoff predicted for the winter period.

\section{Conclusions}

The aim of this study was to detect the impact of land use and climate change on the extreme runoff regimes in selected catchments of Slovakia, with an emphasis on selected characteristics of the hydrological regimes, catchment runoff and, especially, design runoff. An evaluation of the scenarios of the long-term mean runoff and their comparison with the reference period of 1981-2010 shows that changes in the long-term mean monthly flows can be expected in the future. These changes may be reflected differently, depending on the land use and climate scenarios.

The KNMI and MPI climate change scenarios represent less extreme changes (the A1B emission scenario). The scenarios considered suggest that practically all the simulated basins could be at risk from summer or autumn droughts. Based on the simulated watersheds in this work, it is likely that this effect will apply to the whole territory of Slovakia. On the other hand, it is possible that the long-term mean monthly runoff will increase in the winter. The lack of water stored as snowpack in the winter could affect the availability of water for the rest of the year. As a result of climate change, there will be an increase of the air temperature in the winter period that could reduce the winter floods.

Because of changes in land use and climate, there will be a decrease in the annual maximum design daily runoff in the winter period according to the land use change scenarios (LU-MPI and LU-KNMI). This decrease is more pronounced using the combination of climate change and land use scenarios than for the climate change scenario without land use change.

The land use changes result in decreasing the design runoff, with more pronounced effects in the Laborec River basin. The increase of grassland areas will reduce the winter floods and accumulation of snow. This change is not so significant in the Váh River basin because this basin is located at higher altitudes.

The results of the simulation are highly dependent on the availability of the input data, the parameterization of land use, the different types of vegetation in the model, and the schematization of the simulated processes; therefore, they need to be interpreted with a sufficient degree of caution and compared with other results from the literature and experimental measurements. Also, the area of the basin plays an important role. The basins analyzed in this study are of medium size. In the case of moderate changes in land use, changes in runoff simulated in the basin outlets would be more evident for smaller catchments. The WetSpa model could respond more sensitively in this case. 
The results could be used in integrated river basin management, especially in the organization of the river basin management process and in assessments of the impacts of changes in the utilization of river basins on runoff and on the extent of erosion-sediment accumulation processes.

\section{Acknowledgements}

This work was supported by the Slovak Research and Development Agency under Contract No. APVV-15-0497 and VEGA Grant Nos. 1/0891/17 and 1/0710/15.

Bibliography

Arnold J.G., Srinivasan R., Muttiah R.S., Williams J.R., 1998, Large area hydrologic modeling and assessment part I: Model development, Journal of the American Water Resources Association, 34 (1), 73-89, DOI: 10.1111/j.17521688.1998.tb05961.x

Blauhut V., Stahl K., Stagge J.H., Tallaksen L.M., De Stefano L., Vogt J., 2016, Estimating drought risk across Europe from reported drought impacts, drought indices, and vulnerability factors, Hydrology and Earth System Sciences, 20 (7), 27792800, DOI: 10.5194/hess-20-2779-2016

Cunnane C., 1988, Methods and merits of regional flood frequency analysis, Journal of Hydrology, 100 (1-3), 269-290, DOI: 10.1016/0022-1694(88)90188-6

DVWK Regeln 101/1999, 1999, Wahl des Bemessungshochwassers, Empfehlung zur berechnung der Hochwasserwahrscheinlichkeit, Verlag Paul Parey, Hamburg, (in German)

Freire-González J., Decker C., Hall J.W., 2017, The economic impacts of droughts: a framework for analysis, Ecological Economics and Management, 132, 196-204, DOI: 10.1016/j. ecolecon.2016.11.005

Hlavčová K., Szolgay J., Kohnová S., Bálint G., 2008, Hydrological scenarios of future seasonal runoff distribution in Central Slovakia, Earth and Environmental Science, 4, 012022, DOI: 10.1088/1755-1307/4/1/012022

Hlavčová K., Lapin M., Valent P., Szolgay J., Kohnová S., Rončák P., 2015, Estimation of the impact of climate change-induced extreme precipitation events on floods, Contributions to Geophysics and Geodesy, 45 (3), 173-192, DOI: 10.1515/congeo-2015-0019

Kulhavý Z., Kováŕ P., 2002, Use of hydrological models for water balance in small watersheds (Využití modelů hydrologické bilance pro malá povodí), VÚMOP, Prague, 123 pp.

Lapin M., Melo M., Damborska I., Vojtek M., Martini M., 2006, Physically and statistically plausible downscaling of daily GCMs outputs and selected results, Acta Meteorologica Universitas Comenianae, 34, 35-57
Lapin M., Bašták I., Gera M., Hrvol’ J., Kremler M., Melo M., 2012, New climate change scenarios for Slovakia based on global and regional general circulation models, Acta Meteorologica Universitatis Comenianae, 37, 25-73

McFarlane D.J., George R.J., Farrington P., 1993, Changes in the hydrologic cycle, [in:] Reintegrating fragmented landscapes, R.J. Hobbs, D. Saunders (eds.), Springer, New York, NY, 146-186

Milly P.C.D., Betancourt J., Falkenmark M., Hirsch R.M., Kundzewicz Z.W., Lettenmaier D.P., Stouffer R.J., 2008, Stationarity is dead: whither water management?, Science, 319 (5863), 573-574, DOI: DOI: 10.1126/science.1151915

Mishra A., Singh V., 2010, A review of drought concepts, Journal of Hydrology, 391 (1-2), 202-216, DOI: 10.1016/j. jhydrol.2010.07.012

Misra A.K., 2014, Climate change and challenges of water and food security, International Journal of Sustainable Built Environment, 3 (1), 153-165, DOI: 10.1016/j.ijsbe.2014.04.006

Refsgaard J.C., Storm B., 1990, Construction, calibration and validation of hydrological models, [in:] Distributed hydrological modelling, M.B. Abbott, J.C. Refsgaard (eds.), Water Science and Technology Library, vol. 22, Springer, Dordrecht, 41-54

Rončák P., 2016, Parameterization of rainfall-runoff models, [dissertation], Faculty of Civil Engineering, Department of Land and Water Resources Management, Slovak University of Technology, Bratislava, 115 pp.

Rončák P., Hlavčová K., Kohnová S., Szolgay J., 2017a, Changes in design discharges in selected catchments in Slovakia in future decades, Acta Hydrologica Slovaca, 18 (2), 174-182

Rončák P., Hlavčová K., Látková T., 2016, Estimation of the effect of changes in forest associations on runoff processes in basins: case study in the Hron and Topla river basins, Slovak Journal of Civil Engineering, 24 (3), 1-7, DOI: 10.1515/sjce2016-0011

Rončák P., Lisovszki E., Szolgay J., Hlavčová K., Kohnová S., Csoma R., Poórová J., 2017b, The potential for land use change to reduce flood risk in mid-sized catchments in the Myjava region of Slovakia, Contributions to Geophysics and Geodesy, 47 (2), 95-112, DOI: 10.1515/congeo-2017-0007

Safari A., Smedtl F., De Moreda F., 2009, WetSpa model application in the Distributed Model Intercomparison Project (DMIP2), Journal of Hydrology, 418-419, 78-89, DOI: 10.1016/j.jhydrol.2009.04.001

Škvarenina J., Mind'aš J., Čaboun V., 1996, Lesné ekosystémy a globálne klimatické zmeny, Zborník referátov z medzinárodného seminára, Zvolen: Lesnícky výskumný ústav, $178 \mathrm{pp}$.

Štefunková Z., Hlavčová K., Lapin M., 2013, Runoff change scenarios based on regional climate change projections 
in mountainous basins in Slovakia, Contributions to Geophysics and Geodesy, 43 (4), 327-350, DOI: 10.2478/ congeo-2013-0019

Tegelhoffová M., 2010, Analysis of the development of a hydrological balance for future decades in the Senianska depression in the Eastern Slovak lowland, Slovak Journal of Civil Engineering, 18 (4), 30-40, DOI: 10.2478/v10189-010-0020-6

The Seventh National Communication of the Slovak Republic on Climate Change, 2017, available at https://unfecc.int/ files/national_reports/annex_i_natcom/submitted_natcom/ application/pdf/976840315_slovakia-nc7-1-7nc_svk.pdf (data access 21.09.218)
Valent P., Rončák P., Maliariková M., Hlavčová K., Randusová, B., 2015, Analysis of land use changes in the Myjava River basin utilizing historical maps, Acta Hydrologica Slovaca, 16 (1), 152-160

Valent P., Rončák P., Maliariková M., Behan Š., 2016, Utilization of historical maps in the land use change impact studies: a case study from Myjava river basin, Slovak Journal of Civil Engineering, 24 (4), 15-26

Wang Z., Batelaan O., De Smedt F., 1996, A distributed model for water and energy transfer between soil, plants and atmosphere (WetSpa), Physics and Chemistry of Earth, 21 (3), 189-193, DOI: 10.1016/S0079-1946(97)85583-8 